\title{
HUBUNGAN ANTARA IKAN CHAETODONTIDAE DENGAN BENTUK PERTUMBUHAN KARANG
}

\author{
Syahnul Sardi Titaheluw*, M Mukhlis Kamal ${ }^{* *}$, Yunizar Ernawati ${ }^{* *}$ \\ *Staf Pengajar FAPERTA UMMU-Ternate, e-mail : titaheluw@gmail.com \\ **Staf Pengajar FIK IPB-Bogor, e-mail : -
}

\begin{abstract}
ABSTRAK
Penelitian ini bertujuan untuk melihat keterkaitan antara ikan Chaetodontidae dengan persentase tutupan karang hidup di perairan sidodadi dan pulau tegal provinsi lampung. penelitian ini dilaksanakan pada bulan Mei sampai Juli 2010 di 6 stasiun. Pengumpulan data dilakukan dengan menggunakan metode sensus visual dan line intercept transect (transek garis) yang ditempatkan sejajar dengan garis pantai. Selama penelitian dijumpai sebanyak 115 jenis ikan Chaetodontidae, mewakili 2 genera; yakni Chaetdon (91 jenis), dan Chelmon (24 jenis). Naik turunnya indeks keanekaragaman, keragaman dan dominansi dapt menjadi indikator kualitas terumbu karang. Keanekaragaman $\left(H^{\prime}\right)$ berkisar antara 0.28-1.38 dan persentase tutupan karang hidup antara 47,94\% sampai $67,14 \%$. Korelasi antara persentase karang hidup dengan ikan Chaetodontidae bersifat positif, dimana koefisien determinan (R) setiap spesies lebih dari $80 \%$. Keanekaragaman jenis rendah yang diikuti oleh dominansi individu dari satu jenis Chaetodontidae mencerminkan adanya kerusakan atau degradasi terumbu karang. Analisis makanan menunjukkan kesukaan ikan Chaetodontidae terhadap karang hidup sangat tinggi, dari semua spesies yang dianalisis kehadiran zooxanthelae sangat tinggi dibandingkan dengan dengan plankton, detritus dan alga. Hal ini menunjukkan bahwa ikan Chaetodontidae sangat tergantung pada karang hidup sebagai makanan utamanya. C. trifasialis merupakan spesies yang paling baik digunakan sebagai spesies indikator untuk menggambarkan kondisi terumbu karang dibandingkan dengan 3 spesies lainnya.
\end{abstract}

Kata Kunci: Chaetodontidae, Terumbu Karang, Sidodadi dan Pulau Tegal.

\section{PENDAHULUAN}

Ekosistem terumbu karang merupakan salah satu ekosistem pemasok pangan yang sangat potensial bagi manusia, karena berbagai jenis biota laut seperti ikan, algae, crusteacea dan molusca dapat ditemukan di ekosistem ini. Kehadiran berbagai jenis biota ini mengundang kegiatan eksploitasi sumberdaya secara besar. Aktivitas penambangan karang, penangkapan ikan dengan bahan beracun dan bahan peledak penggunaan alat tangkap yang tidak selektif serta pencemaran yang terjadi di laut maupun di darat merupakan masalah utama terjadinya degradasi terumbu karang. Pengaruh perubahan mutu lingkungan akibat kegiatan pemanfaatan sumberdaya ekosistem terumbu karang dapat di identifikasi dengan melihat indikator fisika, kimia dan biologi. Dari indikator biologi, perubahan ekosistem terumbu karang dapat digambarkan dengan kehadiran jenis ikan famili Chaetodontidae. Jenis ikan ini sangat bergantung pada karang, yang merupakan tempat untuk mencari makan dan berlindung, maka distribusinya dan densitasanya lebih banyak dipengaruhi oleh tutupan karang.

Reese (1977) menyatakan bahwa ikan 
famili Chaetodontidae dapat dijadikan indikator kesehatan ekosistem terumbu karang, karena kesukaannya terhadap jenis substrat tertentu yang dapat menggambarkan kondisi terumbu karang. Bouchon (1989), Hutomo dan Adrim (1985), Bell dan Galzin (1984) menunjukkan tutupan terumbu karang meningkat berkorelasi positif dengan ikan Chaetodontidae Lebih lanjut Bell et al (1985) menyatakan bahwa kerapatan penutupan karang keras semakin padat pada suatu ekosistem terumbu karang akan berdampak pada semakin banyaknya polip karang yang hidup. Dalam hal ini berhubungan langsung pada meningkatnya makanan yang dikonsumsi oleh ikan Chaetodontidae yang bersifat obligatif coralivor, sehingga dapat meningkatkan kelimpahan ikan Chaetodontidae.

Perairan Sidodadi dan Pulau Tegal merupakan perairan yang dimanfaatkan oleh masyarakat untuk kegiatan perikanan, dalam hal ini sebagai sentral Keramba Jaring Apung (KJA). Sebagai sentral budidaya laut (marine culture) sudah tentu kondisi perairan harus mendukung atau harus dijaga untuk mendzsukung kegiatan tersebut. Perairan Sidodadi dan Pulau Tegal juga merupakan tempat wisata dengan akses masuk dari pantai ringgung.

\section{METODE PENELITIAN}

Penelitian ini dilaksanakan pada bulan Mei-Juli 2010 di 6 stasiun pada perairan Sidodadi dan Pulau Tegal Propinsi Lampung. Penilaian kondisi terumubu karang menggunakan metode line intercept transect (LIT) atau metode transek garis menyinggung yaitu dengan cara membentangkan roll meter sepanjang 50 meter dengan posisi sejajar garis pantai (English et al., 1994). Data ikan karang diperoleh dengan metode pengamatan visual (visual census method) dengan menggunakan transek garis yang sama untuk pengamatan data karang. Pencatatan data ikan karang dilakukan dengan menyelam di atas transek garis sepanjang $\mathbf{5 0}$ meter sambil mencatat seluruh spesies seluruh ikan dan kelimpahannya yang ditemukan sejauh 2,5 m ke kiri dan 2,5 m ke kanan dari garis transek garis sehingga luasan pengamatan $250 \mathrm{~m}^{2}$. Pengamatan ikan karang dan terumbu karang dilakukan pada kedalaman 5 meter disemua stasiun. Peralatan yang digunakan adalah peralatan selam (SCUBA), alat tulis bawah air, buku identifikasi menurut Kuiter and Tonozaka (2001) dan meteran tali (meteran roll). Transek sepanjang $\mathbf{5 0}$ meter dibuat sejajar garis pantai, dengan pengamatan memakai garis khayal sejauh 5 meter. Ikan-ikan yang dijumpai diamatai jenisnya dan dicatat sepanjang garis transek tersebut.

Untuk mengetahui persentase tutupan karang hidup dan berbagai indeks ekologi seperti: indeks mortalitas (IM), indeks kelimpahan (Ni), indeks keanekaragaman (H), indeks dominansi (D), indeks keseragaman (E), Shannon-Wiener. Sedangkan untuk melihat keterkaitan antara ikan Chaetodontidae dengan terumbu karang digunakan analisis regresi sederhana dengan menggunakan program Excel 2007.

\section{HASIL DAN PEMBAHASAN}

3.1. Tutupan karang hidup

Secara umum, rerata persentase tutupan karang hidup di Perairan Sidodadi dan Pulau Tegal adalah 59,57 \% yang artinya kondisi terumbu karang pada lokasi penelitian masih dalam kategori baik menurut Kepmen LH No 4 (2001). Dari 6 stasiun yang diamati, hanya pada stasiun 1 yang persentase tutupan karangnnya dalam kondisi sedang, yakni sebesar $47.94 \%$ (Gambar 2). Stasiun 1 merupakan lokasi yang sering dijadikan sebagai tempat pengeboman oleh nelayan sekitar 10 - 11 tahun belakangan. Faktor tersebut merupakan salah satu penyebab atau mempercepat proses terjadinya degradasi ekosistem terumbu karang pada stasiun 1 . Walaupun stasiun 3 dan 6 dalam kategori baik, namun pada stasiun tersebut sering dilakukan pengambilan batu karang oleh masyarakat sekitar khususnya pada stasiun 6. Dari hasil pengamatan lapangan dan menurut masyarakt, pengambilan mereka lakukan untuk breakwater yang mereka lakukan. Sedangkan pada stasiun 3, merupakan lokasi baru untuk aktivitas destructive fishing khususnya bom. Stasiun 2 dan 4 merupakan lokasi yang dimanfaatkan potensi terumbu karang nya, sehingga terbentuknya suatu pengawasan oleh masyarakat sendiri. 
Karena adanya pengawasan tersebut, maka ekosistem turumbu karang akan dijaga oleh masyarakat yang memanfaatkan ekosistem tersebut. Kondisi ini akan mempengaruhi interaksi antara yang terjadi dalam ekosistem terumbu karang tersebut. Hal ini dapat terlihat pada nilai-nilai keanekaragman dan keseragman (tabel 3) yang ditemukan pada lokasi penelitian. Tingginya nila-nilai tersebut dikarenakan jumlah makanan yang tersedia pada stasiun 2 dan 4 masih mencukupi bagi kebutuhan ikan-ikan karang tersebut.

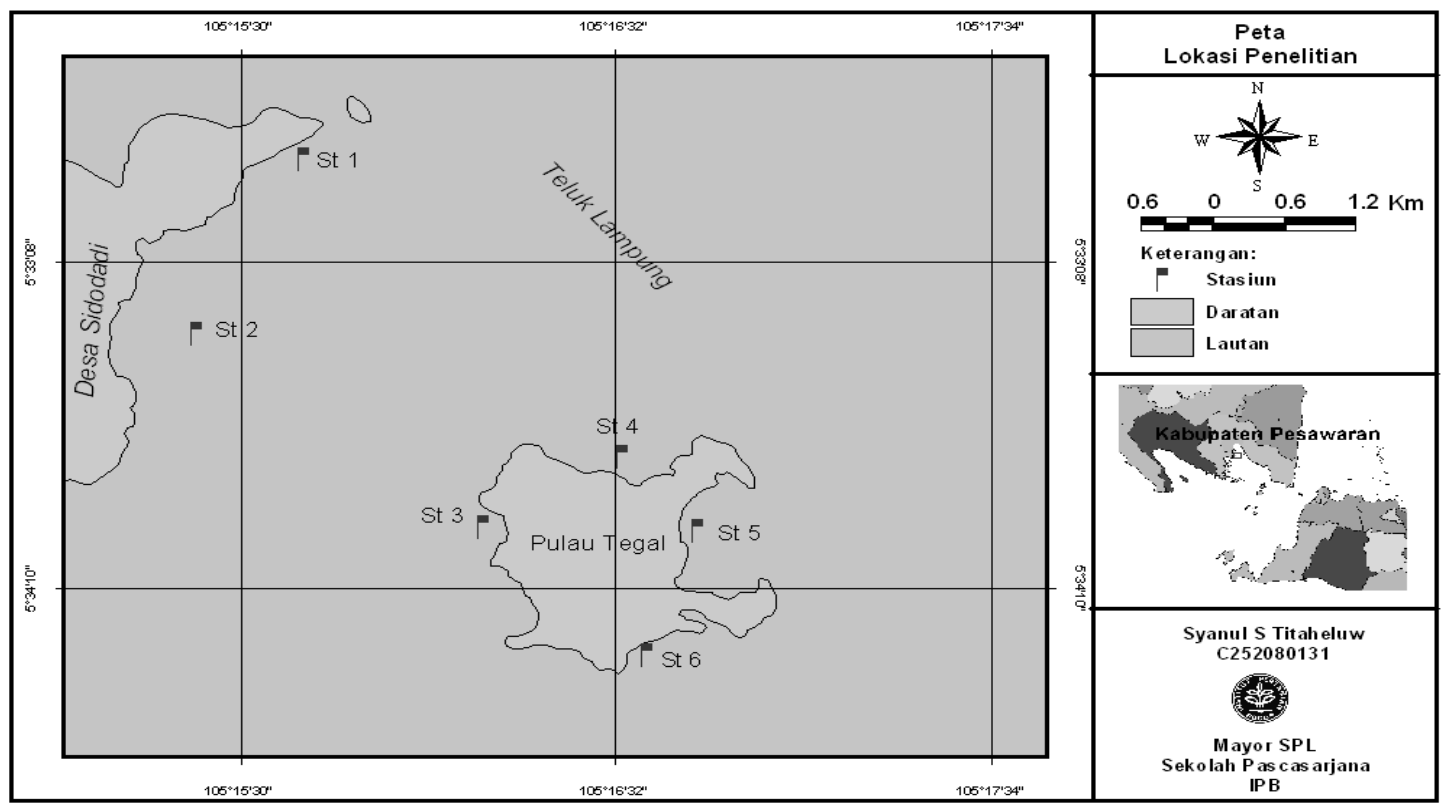

Gambar 1. Lokasi Penelitian Di Perairan Sidodadi Dan Pulau Tegal

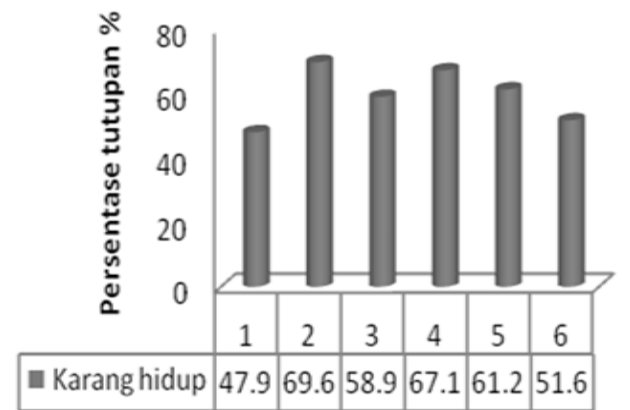

Gambar 2 persentase tutupan karang hidup

\subsection{Indeks mortalitas}

Tingginya tingkat mortalitas pada stasiun 1 (Gambar 3) dikarenakan lokasi tersebut tidak adanya pengawasan atau bentuk pemanfaatan oleh masyarakat sekitar, sehingga dengan mudah kegiatan-kegiatan perikanan yang merusak berlangsung. Pada stasiun 5 sering dijadikan sebagai persinggahan kapal-kapal nelayan atau sebagai lokasi berlindung dari hempasan gelombang. Buangan jangkar dari kapal-kapal

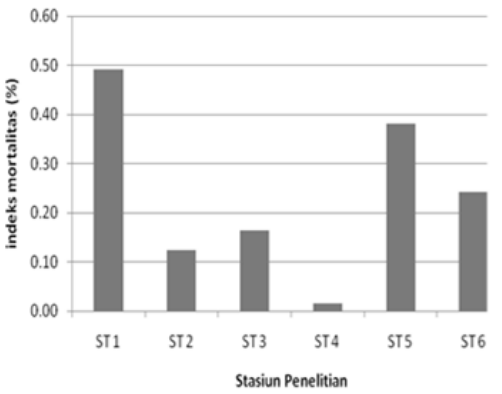

Gambar 3 tingkat mortalitas karang pada semua stasiun

nelayan saat berlindung tersebut menyebabkan karang menjadi patah dan stasiun 6 merupakan lokasi pengambilan batu karang untuk breakwater. Berbeda dengan stasiun 2 dan 4 yang digunakan sebagai lokasi Keramba Jaring Apung (KJA), maka kegiatan-kegiatan yang merusak tersebut dapat ditekan dengan adanya pengawasan secara tidak langsung dari para pekerja dan pemilik keramba yang beroperasi. Lokasi-lokasi yang tidak ada pengawasannya 
(stasiun 1, 5 dan 6) lebih tinggi peluang terjadinya kegiatan-kegiatan perikanan yang merusak dibandingkan dengan yang ada pengawasan. Konsekuensi dari tidak adanya pengawasan tersebut akan menyebabkan proses degradasi terumbu karang makin cepat terjadi.

\subsection{Total ikan karang}

Jumlah total ikan yang tersensus selama penelitian sebanyak 684 ekor yang terdiri dari 7 Genera ikan mayor, 2 Genera ikan indikator (Chaetodontidae) dan 5 Genera ikan target di seluruh stasiun. Ikan mayor merupakan genera yang mendominasi di semua stasiun dibandingkan dengan target dan indikator. Secara umum ikan-ikan ini juga lebih banyak pilihan makanannya atau ikan ini kebanyakan bersifat omnivora dibandingkan dengan ikan indikator yang sangat tergantung dengan tutupan karang hidup di perairan walupun sebagian bersifat omnivora juga. Manurut Hiatt \& Strasburg (1960) diacu dalam Bawole dan Hukom (1997), ikan-ikan ini tersebut termasuk dalam kelompok omnivora yang memakan krustacea, pelecipoda, detritus dan alga. Selain itu, ikan ini sering dijumpai dalam jumlah yang banyak di bandingkan dengan ikan jenis lainnya. Karena termasuk dalam kelompok omnivore, berarti bahwa pilihan makanan sangat banyak sehingga tidak tergantung pada satu jenis makanan saja.

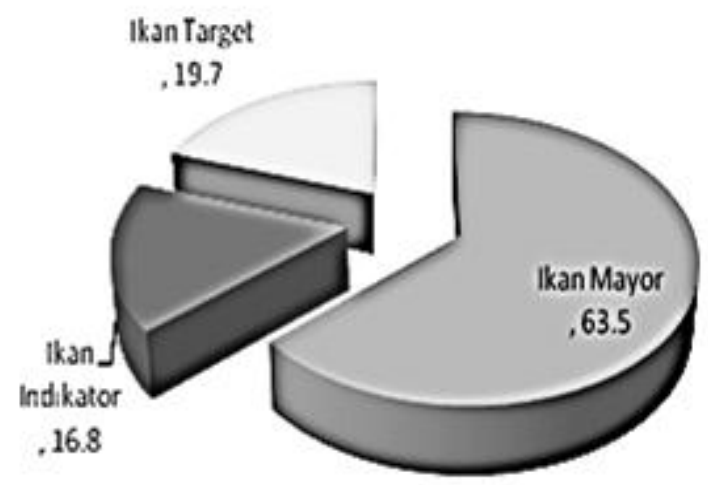

Gambar. 4 Komposisi Total Ikan di 6 LokasiPenelitian.

Berbeda halnya dengan ikan Chaetodontidae yang sangat tergantung pada makanan, dimana jenis makanan utamanya merupakan polip karang, sedangkan polip karang sangat ditentukan oleh tutupan karang hidup. Sehingga kelimpahan dan distribusi dari ikan Chaetodontidae sangat tergantung pada tutupan karang hidup di perairan tersebut. Menurut Reese (1981) sekitar 50 \% ikan famili Chaetodontidae merupakan pemakan polip karang. Adrim et al., (1991) mengatakan ikan Chaetodontidae sangat sensitif terhadap perubahan dan kerusakan terumbu karang.

Kecilnya kehadiran ikan target ini dikarenakan tingginya destructive fishing yang terjadi khususnya bom beberapa tahun belakangan dilokasi penelitian. Selain penggunaan bom, pengambilan batu karang juga ikut mempercepat proses degradasi terumbu karang yang terjadi di lokasi penelitian tersebut. Jika mengacu pada kategori Manuputty dan Djuwariah (2006) kelimpahan ikan target yang tersensus di lokasi penelitian termasuk dalam kategori yang sedikit. Kelimpahan ikan target yang tersensus tidak lebih dari 40 ekor dalam satu transek dan pada semua stasiun.

\subsection{Ikan Chaetodontidae}

Tercatat sebanyak 115 spesies ikan Chaetodontidae yang termasuk dalam 2 Genera yang ada di Perairan Sidodadi dan Pulau Tegal. Chaetodon merupakan Genera yang mendominasi di setiap stasiun (3 jenis), dan Chelmon (1 jenis). Tidak jauh berbeda dengan beberapa hasil penelitian yang di lakukan oleh Hukom (1994), Adrim (2001), menemukan 6 Genera ikan Chaetodontidae di perairan Derawan yang didominasi oleh Genera Chaetodon, Makatipu (1998) menemukan 4 jenis Chaetodontidae, yang didominasi oleh famili Chaetodon sebanyak 19 jenis.

Bila dibandingkan dengan beberapa penelitian yang di laporkan di perairan Indonesia, jumlah Genera Chaetodontidae dalam kategori yang rendah dan hanya terdapat 2 Genera dengan jumlah jenis sebanyak 4 jenis yang tersensus selama penelitian. Rendahnya Genera yang ditemukan tersebut diduga karena tingginya tekanan ekologi pada terumbu karang akibat dari kegiatan destructive fishing tersebut. 
Tabel 1. Jumlah Genera Dan Jenis Ikan Chaetodontidae Dari Beberapa Penelitian yang Dilakukan di Perairan Tropik

\begin{tabular}{|c|c|c|c|}
\hline Lokasi & Genera & Jenis & Pustaka \\
\hline \multicolumn{4}{|l|}{ Perairan Indonesia; } \\
\hline Teluk Ambon & 4 & 27 & Bawole, 1998 \\
\hline Selat Sunda & 3 & 29 & Hutomo et al, 1991 \\
\hline Kepualauan Seribu & 5 & 19 & Adrim et al, 1991 \\
\hline Sulawesi Utara & 6 & 32 & Adrim, 2001 \\
\hline Sidodadi \& Tegal & 2 & 4 & Studi sekarang \\
\hline \multicolumn{4}{|l|}{ Di Luar Indoneisa; } \\
\hline Teluk Agaba & 2 & 8 & Harmeli et al., 1981 \\
\hline Polinesia Prancis & 1 & 12 & Bell \& Ghalzin, 1984 \\
\hline Singapura & 4 & 4 & Lim \& Chou, 1991 \\
\hline Teluk Thailand & 3 & 3 & Satumanatpan et al., 1991 \\
\hline
\end{tabular}

Chaetodon octofasciatus merupakan jenis yang mendominasi di setiap stasiun pengamatan. Jumlah Chaetodon octofasciatus tertinggi pada stasiun 1 sebanyak 11 ekor, ini berkaitan dengan tutupan karang Acroporidae yang tinggi dibandingkan dengan stasiun lainnya. Ikan jenis octofasciatus lebih sering ditemukan pada karang suku Acroporidae atau karang Acropora sebagai tempat tinggal, reproduksi dan juga makanan (Navaro et al. 1985; Manthacitra et al. 1991; Adrim et al. 1991). Lebih jauh menurut Madduppa (2006) karang dari suku Acroporidae mempunyai kandungan protein lebih tinggi dibandingkan dengan karang dari suku lainnya, seperti Fungidae dan Porites. Coles dan Strathman (1973) dalam Alwany et al. (2003) menambahkan bahwa lendir karang merupakan sumber energi dan nutrien. Benson \& Muscatine (1974) melaporkan bahwa lendir dari Acropora mempunyai kandungan karbon yang lebih kaya di bandingkan dengan Porites.

Keanekaragaman Chaetodontidae tertinggi pada stasiun 2 dan 4 (1.38), sedangkan terendah pada stasiun 1 (0.29). Stasiun-stasiun yang memiliki keanekaragaman yang tinggi tersebut mencirikan adanya suatu bentuk pengawasan terhadap terumbu karang, dalam hal ini dimanfaatkan sebagai lokasi budidaya ikan kerapu. Pengawasan tersebut memberikan suatu perlindungan bagi ekosistem terumbu karang dan tekanan terhadap para nelayan pembom. Sehingga tekanan ekologi terhadap ekosisitem terumbu karang dari kegiatan destructive fishing dapat dikontrol. Hal ini menyebabkan persentase tutupan karang hidup akan meningkat, yang berdampak pada semakin banyak polip karang yang hidup sehingga persediaan makanan akan berlimpah. Bell et al. (1985) mengatakan meningkatnya jumlah karang hidup akan berdampak langsung pada makanan yang dikonsumsi oleh ikan obligatif koralivora, sehingga dapat meningkatkan kelimpahan ikan famili Chaetodontidae. Menurut Odum (1975) diacu dalam Edrus dan Syam (1998) keragaman biota merupakan bikti yang digunakan untuk melihat ada tidaknya tekanan terhadap lingkungan yang diakibatkan oleh eksplorasi atau populasi.

Tabel 2. Kelimpahan, Keanekaragaman, Keseragaman dan Dominansi jenis ikan di Perairan Sidodadi dan Tegal.

\begin{tabular}{lllllll}
\hline Indeks & St 1 & St 2 & St 3 & St 4 & St 5 & St 6 \\
\hline Kelimpahan (Ni) & 0.05 & 0.11 & 0.06 & 0.12 & 0.07 & 0.06 \\
Keanekaragaman $\left(\mathrm{H}^{\prime}\right)$ & 0.29 & 1.38 & 1.31 & 1.38 & 1.35 & 1.03 \\
Keseragaman (E) & 0.41 & 0.99 & 0.94 & 1.00 & 0.98 & 0.74 \\
Dominansi (C) & 0.85 & 0.25 & 0.29 & 0.25 & 0.27 & 0.46 \\
\hline
\end{tabular}


Stasiun 1 mempunyai nilai-nilai indeks paling rendah di bandingkan dengan stasiun yang lainnya; baik kelimpahan, keanekaragaman dan keseragaman. Rendahnya nilai-nilai indeks pada stasiun 1 tersebut menggambarkan tekanan ekologi yang cukup tinggi. Tingginya tekanan menyebabkan interaksi komunitas ikan Chaetodontidae didominasi oleh satu spasies. Disisi lain, rendahnya nilai indeks di stasiun 1 tersebut akibat dari tidak adanya pengawasan dan merupakan lokasi pengeboman beberapa tahun belakangan. Mac Lennan dan Simmond 1992 diacu dalam Subandi (2005) menyatakan bahwa gelombang kejut yang terbentuk dari dalam air menjadi penyebab utama kerusakan atau luka pada tubuh ikan. Salah satu dampak serius yang ditimbulkan oleh penggunaan bahan peledak adalah koloni baru tidak tumbuh pada area peledakan meskipun area tersebut terlindungi dari dampak peledakan-peledakan berikutnya. Karena penggunaan didaerah terumbu karang, maka akibat langsungnya yaitu mengakibatkan kerusakan fisik terumbu (Riegl dan Luke 1999; Fox et al.2003; Fox et al. 2005), terutama karang branching dan foliose (Pet dan Erdam, 1998). Kondisi demikian mengakibatkan kehilangan tutupan karang hidup hingga 3,75\% $\mathrm{m}^{2}$ per $100 \mathrm{~m}^{2}$ setiap tahun (Soede et al. 1999).

Kegiatan-kegiatan antropogenik tersebut memberikan tekanan yang sangat berarti bagi terumbu karang dan ikan karang, baik target, mayor dan Chaetodontidae (collare, trifascialis octofasciatus dan rostratus), dimana terumbu karang sebagai sumber makanannya hilang. Tingginya keanekaragman, keseragaman dan dominansi pada stasiun 2 dan 4 merupakan implikasi dari aktivitas perikanan yang ada di stasiun tersebut. Kegiatan perikanan tersebut memberikan sutu jaminan "pengawasan" terhadap ekosistem terumbu karang dari aktivitas nelayan yang tidak ramah lingkungan, seperti penggunaan bom dan sebagainya.

3.4. Hubungan persentase tutupan karang hidup dengan ikan Chaetodontidae

Untuk melihat hubungan antara persentase penutupan karang hidup dengan kelimapahan famili Chaetodontidae digunakan analisis regresi
(Bouchan 1989, Bell \& Galzin 1984). Hasil analisis menunjukkan adanya respon linier positif antara jumlah ikan Chaetodontidae terhadap persentase tutupan karang hidup, dengan koefisien determinasi $\left(R^{2}\right)$ sebesar 0.802 (gambar 4). Sehingga dapat dikatakan semakin besar persentase tutupan karang hidup, semakin tinggi jumlah Chaetodontidae. Peningkatan jumlah karang hidup tersebut akan berdapak pada ketersediaan jumlah makanan ikan Chaetodontidae yang melimpah. Dimana persentase tutupan karang yang baik akan berdampak pada semakin banyak polip karang yang hidup sehingga persediaan makanan akan berlimpah. (Bell et al. 1985) mengatakan meningkatnya jumlah karang hidup akan berdampak langsung pada makanan yang dikonsumsi oleh ikan obligatif koralivora, sehingga dapat meningkatkan kelimpahan ikan famili Chaetodontidae. Kondisi ini sesuai dengan hasil yang ditemukan dalam penelitian ini, dimana pada stasiun 2 dan 4 jumlah spesies lebih banyak di bandingkan dengan stasiun lainnya. Selanjutnya hal yang sama juga ditemukan oleh Chabanet et al. (1997) dan Bouchon (1989) bahwa ada hubungan positif antara persentase substrat terumbu karang dengan kehadiran ikan Chaetodontidae. Karena ketergantungannya terhadap karang sebagai makanan dan tempat berlindung, maka distribusinya lebih banyak dipengaruhi oleh kondisi tutupan karang hidup.

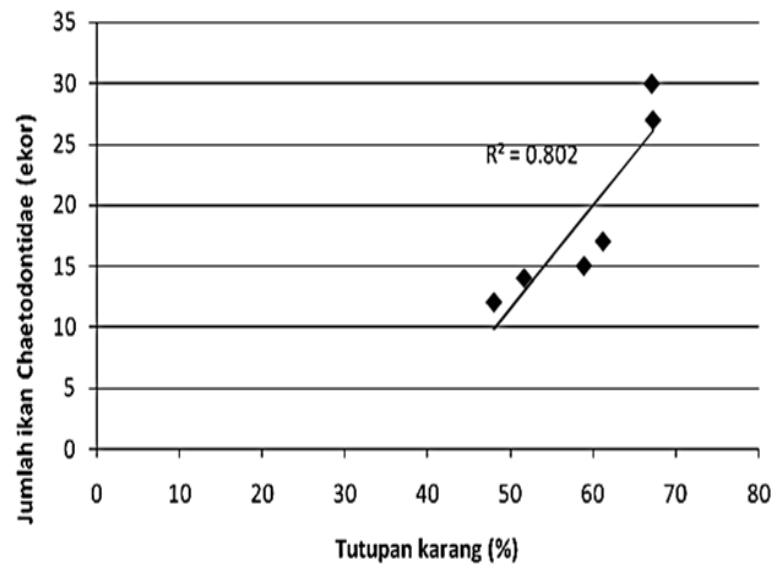

gambar 4. Hubungan Regresi Ikan Chaetodontidae Dengan Tutupan Karang Hidup 


\subsection{Analisis makanan}

Dari hasil analisis makanan menunjukkan zooxanthelae merupakan makanan yang paling disukai oleh spesies ini atau sebagai makanan utama. Sehingga kehadiran ikan ini dapat gunakan menggambarkan kondisi terumbu karang disuatu perairan. Semua jenis Chaetodontidae sangat tergantung pada tutupan karang hidup sebagai makanan utamanya. Tutupan karang hidup yang rendah disatu perairan maka keanekaragaman dari spesies Chaetodontidae juga akan rendah begitupun sebaliknya dengan tutupan karang yang tinggi.

Dari semua jenis Chaetodontidae yang dianalisis, terlihat Chaetodon trifascialis merupakan spesies yang paling tergantung pada tutupan karang hidup, dimana persentase jenis makanan zooxanthelae sangat tinggi dibandingkan dengan jenis makanan yang lainnya. Hal ini sangat berkaitan dengan penelitian, dimana kelimpahan dari spesies ini tertinggi pada stasiun 2 dan 4 yang mempunyai tutupan karang hidup lebih baik dibandingkan dengan stasiun lainnya. Selain itu spesies ini juga merupakan spesies yang Obligate corallivores $(\mathrm{OC})$ atau spesies yang sepanjang hidupnya memakan karang, dimana zooxanthelae merupakan makanan utamanya. Kondisi seperti inilah yang menyebabkan spesies trifascialis paling baik dijadikan sebagai spesies indikator untuk melihat perubahan atau degradasi ekosistem terumbu karang.

Tabel 3. Komposisi Jenis Makanan per Spesies

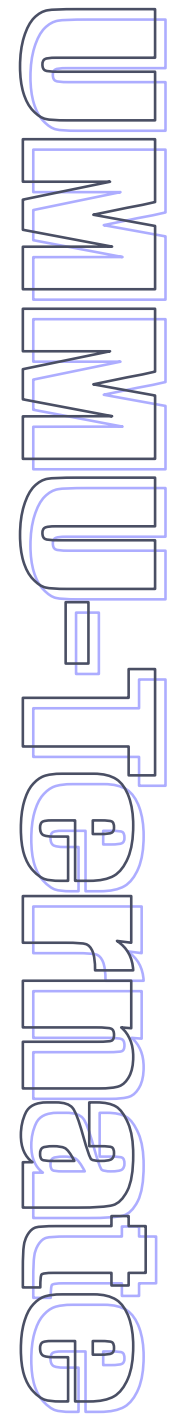

\begin{tabular}{|c|c|c|}
\hline Spesies & Jenis Makanan & Index of Preponderance \\
\hline \multirow[t]{9}{*}{ C. octofasciatus } & Detritus & 30.27 \\
\hline & Zooxanthelae & 66.32 \\
\hline & Plankton & \\
\hline & Bacillariophyliceae & 1.14 \\
\hline & Cyarophyceae & 0.33 \\
\hline & Bag. Tanaman & 0.05 \\
\hline & Bag. Hewan & 1.61 \\
\hline & Algae & 0.14 \\
\hline & Malacorhaca & 0.14 \\
\hline \multirow[t]{8}{*}{ C. collare } & Detritus & 12.53 \\
\hline & Zooxanthelae & 64.07 \\
\hline & Plankton & \\
\hline & Bacillariophyliceae & 17.19 \\
\hline & Cyarophyceae & 2.48 \\
\hline & Bag. Tanaman & 1.83 \\
\hline & Bag. Hewan & 0.98 \\
\hline & Algae & 0.91 \\
\hline Spesies & Jenis Makanan & Index of Preponderance \\
\hline \multirow[t]{4}{*}{ C. trifascialis } & Detritus & 19.98 \\
\hline & Zooxanthelae & 79.97 \\
\hline & Plankton & \\
\hline & Bacillariophyliceae & 0.05 \\
\hline \multirow[t]{7}{*}{ Chelmon rostratus } & Detritus & 56.26 \\
\hline & Zooxanthelae & 19.50 \\
\hline & Plankton & \\
\hline & Bacillariophyliceae & 22.12 \\
\hline & Cyarophyceae & 0.23 \\
\hline & Bag. Tanaman & 1.83 \\
\hline & Algae & 0.06 \\
\hline
\end{tabular}




\section{PENUTUP}

Secara umum kondisi terumbu karang di Perairan Sidodadi dan Pulau Tegal dalam kondisi baik. Kerusakan terumbu karang di Perairan Sidodadi dan Pulau Tegal merupakan implikasi dari tidak adanya pengawasan yang menyebabkan kegiatan destructuive fishing khususnya bom dengan mudah dilakukan. Aktivitas pengeboman merupakan faktor utama yang mempercepat proses degradasi terumbu karang di perairan tersebut. Salah satu bentuk pengawasan yang paling bagus diterapkan dilokasi penelitian ialah dengan memanfaatkan potensi terumbu karang yang ada sebagai keramba jaring apung tanpa melewati batas daya dukung dari ekosistem sendiri. Jumlah genera ikan Chaetodontidae yang ditemukan dalam kategori yang renda jika dibandingkan dengan beberapa penelitian di perairan Indonesia dan Chaetodon octofasciatus lebih suku tinggal pada daerah yang tutupan karang Acropora lebih tinggi di bandingkan dengan karang jenis lain.

Kelimpahan ikan Chaetodontidae akan meningkat seiring dengan tingginya persentase tutupan karang hidup. Hal ini dikarenakan spesies ini sangat tergantung pada tutupan karang hidup sebagai makanan utama.
Perubahan persentase tutupan karang hidup mempengaruhi kelimpahan dan cendrung dominansi oleh salah satu spesies karena keterkaitannya dengan makanan dan tempat berlindung. Analisis makanan menunjukkan ikan Chaetodontidae sangat tergantung pada tutupan karang hidup sebagai makanan, tempat tinggal dan memijah. Zooxanthelae merupakan makanan utama dari ikan Chaetodontidae, baik yang bersifat Obligate Corallivores (OC), Facultative Corallivores (FC). Spesies trifasialis lebih sedikit mempunyai pilihan makanan dibandingkan dengan spesies collare, octofasciatus dan Chelmon rostratus. Spesies trifascialis paling baik digunakan sebagai spesies indikator untuk melihat perubahan tutupan karang. Ini dikarenakan jenis makanan yang dikonsumsi oleh spesies tersebut.

Peranan semua stakeholder sangat dibutuhkan untuk mencapi pengelolaan yang baik, karena pada dasarnya semua kegiatan pengelolaan baik terumbu karang maupun ikan Chaetodontidae lebih ditekankan kepada mayarakat yang berhubungan langsung dengan ekosistem, keterlibatan ini dapat menentukan baik buruknya ekosistem.

\section{DAFTAR PUSTAKA}

Adrim M. 2001. Distribusi Spasial Ikan Kepe-Kepe (Suku: Chaetodontidae) Di Wilayah Pesisir Utara Darin Sulawesi Utara. Bidang Sumberdaya Hayati Laut P2O-LIPI Jakarta. 25-34.

Adrim M, Hutomo M, Suharti S R. 1991. Chaetodontid fish community Structure and Its Relation to Reef Degradation at the Seribu Islans Reefs, Indonesia. Proceedings of the Regional Symposium on Living Resources in Coastal Areas. Phillipine.

Alwany M, Thaler E and Stacowitch M. 2003. Food selection in two coralivorous butterflyfishes, Chaetodon autricus and C. trifascialis in the North Red Sea. Marine Ecology, 24 (3) : 165-167.

Anderson GRV, Ehrlich AH, Ehrlich PR, Roughgarden DB, Russel C and Talbot FH. 1981. The Community Structure of Coral Reef Fishes. American Naturalist, 117: 476-495.

Bawole R. 1998. Distribusi Spasial Ikan Chaetodontidae Dan Peranannya Sebagai Indikator Kondisi Terumbu Karang Di Perairan Teluk Ambon. Tesisi. Insitut Pertanian Bogor. Bogor.

Bell JD, Galzin R. 1984. Influnce life coral cover on coral reef fish community. Mar. Ecol, Prog. Ser. 15: 265-274.

Bell JD, Harmelin-Vivien and Galzin R. 1985. Large Scale Spatial Variation in Abudance of Butterflyfishes (Chaetodontidae) on Polynesia Reefs. Proceeding of the $5^{\text {th }}$ International Coral Reef Congress, Tahiti. Pp. 421-426. 
Bouchan-Navaro Y, Bouchan C. 1989. Corelations between Chaetodontidaetid fishes and coral communities of the gulf of aqaba (Red Sea). Envioromental Biologi of Fishes (25): 47-60.

Chabanet P, Ralambondrainy H, Amanieu M, Faure G, Galzin R. 1997. Relationships between coral reef subtrata and fish. Coral Reefs (16): 93-102.

Edrus I N dan Syam A M, 1998. Sebaran Ikan Hias Chaetodontodae di Perairan Karang Pulau Ambon dan Peranannya dalam Penentuan Kondisi Terumbu Karang. Jurnal Penelitian Perikana Indonesia. Vol. IV No. 3. 1-10.

English S, Wilkinson C, Baker V. 1994. Survey Manual for 1 Tropical Marine Resources. Australian Institute of Marine Science. Fownsville: 390 p.

Fox H, Pet J S, Dahuri R and Roy L W, 2003. Recovery in Rubbel Fields: Long-Term Impact of Blast fishing. Marine Pollution Bulletin. 46: 1024-1031.

Fox H, Peter JM, Mouse, Pet J S, Muljadi M and Roy L C. 2005. Experimental Assesesment of Coral Reef Rehabilitation Following Blast Fishing. Conservation Biology. Vol 19, No 1: 98-107.

Hermerlin-Vivien M L and Bouchon. 1981. Trophic Relationships among Chaetodontid Fishes in the Gulf of Aqaba (Red Sea). Proceeding of the $4^{\text {th }}$ International Coral Reef Symposium. Manila, 2: 537-544.

Hukom, FD, Bawole R. 1997. Family Chaetodontidae Sebagai Ikan Indikator di Daerah Terumbu Karang. Vol XX. 1-6.

Hukom, FD. 1994. Asosiasi Antara Ikan Komunitas Ikan Karang (Famili Chaetodontidae) Dengan Bentuk Pertumbuhan Karang Di Perairan Kepulauan Derawan Kalimantan Timur. Balitbang Biologi Laut. Pustlitbang Oseanologi LIPI Jakarta. 165-174.

Hutomo M, Suharti S R and Harahap I H. 1991. Spatial Variability in the Chaetodontid Fish Community Structure of Sunda Strait Reefs. Proceeding of the Regional Symposium on Living Resources in Coastal Area, Philippine. pp. 151-161.

Hutomo M \& Adrim M. 1986. Distribution of Reef Fish along Trancects in Bay of Jakarta and Kepulauan Seribu. Mar. sci, 40: 135-156.

Krebs CJ. 1972. Ecologi : the Experimenthal Analisys of Distribution and Abudance. Harper and Row Publisher. New York. 694 p.

Kuiter RH and Tonozaka T. 2001. Pictorial Guide to: Indonesia Reef Fishes. Part 1, 2 and 3. Zoo Netics, Seaford Victoria, Australia.

Lim G S Y and Chou L M. 1991. Studies of Reef Communities in Singapore. Proceeding of the Regional Symposium on Living Resources in Coastal Area. Philippine, pp. 117-127.

Maduppa HH. 2006. Kajian Ekobiologi Ikan Kepe-Kepe (Chaetodon octofasciatus, BLOCH 1787) Dalam Mendeteksi Kondisi Ekosistem Terumbu Karang Di Pulau Petondan Timur, Kepulauan Seribu, Jakarta. Tesis. Insitut Pertanian Bogor. Bogor.

Makatipu PC. 1998. Studi Pendahuluan Komunitas Ikan Kepe-Kepe (Chaetodontidae) Di Perairan Terumbu Karang Selat Lembeh, Bitung, Sulawesi Utara. Studi Penelitian LIPI-Bitung. 121128.

Manuputty Anna EW \& Djuwariah. 2006. Panduan metode point intercept transect (PIT) untuk masyarakat. Studi Baseline dan Monitoring Karang di Lokasi Daerah Perlindungan Laut (DPL) COREMAP II - LIPI, Jakarta. 32 hal.

Manthacitra VS, Sudara S, Satumanatpan S. 1991. Chaetodon octofasciatus as indicator species for reef condition. Proceedings of the 5th regional Symposium in Coastal Areas, Manila . Pp:135-138.

Menteri Negara Lingkungan Hidup. 2001. Kepmen LH No. 4 Tahun 2001 tentang kriteria baku kerusakan terumbu karang.

Pet SL and Erdam. 1998. Blast Fishing in Southwest Sulawesi Indonesia. Naga, the ICLARM Quarterly. 
Reese. 1981. Predation on coral by fishes of the family Chaetodontidae: implementation for conservation and management of coral reef ecosystem. Bull. Mar. Sci.: 31 : 594-604.

Reese. 1977. Coevolution of corals and coral feeding fishes of the family Chaetodontidae: Implication for conservation and management of coral reef ecosystems. Bulletin of Marine Science (31): 594604.

Riegl B and Luke K E, 1999. Ecological Parameters of Dynamited Reefs in the Northen Red Sea and their Relevance to Reef Rehabilitiation. Marine Pollution Bulletin Vol. 37, Nos. 8-12, pp. 488498.

Satumanaptan S, Sudara S and Sookchanuluk C. 1991. Comparision of Reef Fish Communities from Various Reef Conditions and Structures in the Gulf of Thailand. The $3^{\text {th }} A S E A N$ Sciense and Technology Week Confrence Proceeding. Singapore, 6: 125-130.

Subandi N, 2005. Pengembangan Metode Ilmia Untuk Pembuktiakan Kasus-Kasus Penangkapan Ikan Dengan Penggunan Bahan Peledak dan Racun Sianida. Tesis. Sekolah Pascasarajana Insitut Pertanian Bogor.

White AT. 1988. Chaeotodon occurence relative to coral reef habitats in the Phipippines with implications for reef assessment. Proceedings of the 6th International Coral Reef Symposium, Australia, Vol.2.

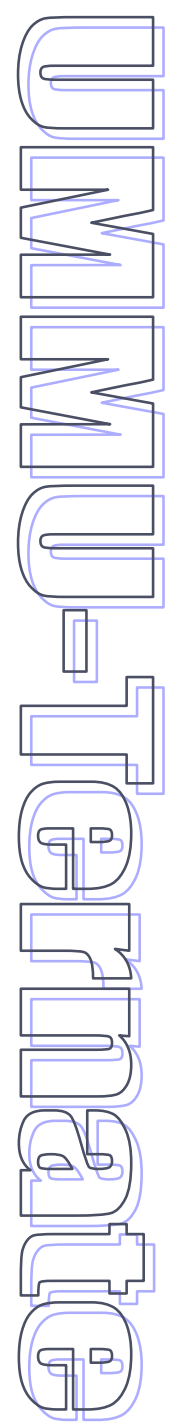

